\title{
Risk Assessments of Water Inrush from Coal Seam Floor during Deep Mining Using a Data Fusion Approach Based on Grey System Theory
}

\author{
Yaru Guo, ${ }^{1,2}$ Shuning Dong $\mathbb{D}^{3},{ }^{3}$ Yonghong Hao $\mathbb{D}^{2},{ }^{2}$ Zaibin Liu $\mathbb{D}^{3,4}$ Tian-Chyi Jim Yeh, ${ }^{2,5}$ \\ Wenke Wang $\left(\mathbb{0},{ }^{4}\right.$ Yaoquan Gao, ${ }^{3}$ Pei Li, ${ }^{3}$ and Ming Zhang $\mathbb{C}^{6}$ \\ ${ }^{1}$ School of Geographic and Environmental Sciences, Tianjin Normal University, Tianjin 300387, China \\ ${ }^{2}$ Tianjin Key Laboratory of Water Resources and Environment, Tianjin Normal University, Tianjin 300387, China \\ ${ }^{3} X i$ 'an Research Institute of China Coal Technology and Engineering Group, Xi'an, Shaanxi 710054, China \\ ${ }^{4}$ School of Water and Environment, Chang'an University, Xi'an, Shaanxi 710064, China \\ ${ }^{5}$ Department of Hydrology and Atmospheric Sciences, The University of Arizona, AZ 85721-0011, USA \\ ${ }^{6}$ Geological Survey of Japan, National Institute of Advanced Industrial Science and Technology (AIST), Tsukuba, \\ Ibaraki 305-8567, Japan
}

Correspondence should be addressed to Shuning Dong; dongshuning@cctegxian.com and Yonghong Hao; haoyh@sxu.edu.cn Received 30 August 2019; Revised 27 December 2019; Accepted 20 January 2020; Published 27 February 2020

Academic Editor: Michele Scarpiniti

Copyright (c) 2020 Yaru Guo et al. This is an open access article distributed under the Creative Commons Attribution License, which permits unrestricted use, distribution, and reproduction in any medium, provided the original work is properly cited.

With the increase in depth of coal mining, the hydrogeological complexity largely increases and water inrush accidents happen more frequently. For the safety of coal mining, horizontal directional drilling and grouting techniques have been implemented to detect and plug the fractures and conduits that deliver high-pressure groundwater to coal mine. Taking the grouting engineering performed at Xingdong coal mine at $980 \mathrm{~m}$ below sea level as an example, we collected the data of grouting quantity, the loss of drilling fluid, gamma value, water temperature, average water absorption, distance between grouting loss points, water pressure on coal seam floor, and aquifuge thickness at 90 boreholes in the mine to conduct grey relational analysis, first. The analysis showed that the grouting quantity was highly correlated with all other factors. Subsequently, grey system evaluation was used to evaluate the risk of water inrush from the coal seam floor. The results of risk analysis illustrated that three water inrushes from Ordovician limestone occurred in mining face 2127, 2125, and 2222 in the study area were all located in the area with a risk score higher than 65. Through grouting, the identified cracks were effectively blocked and waterproof layers beneath the coal seam floors were constructed to reduce the threat of water inrush. By comparing the risk assessment results with three water inrush cases before grouting operation, we found that water inrush areas were consistent with the area of higher risk.

\section{Introduction}

With the increase in depth of coal mining, groundwater pressure increases largely that leads to more random fractures and conduits connect coal bed and underneath rock formation [1-3]. The complexity of hydrological conditions increases the hazards of water inrush in deep coal mining, worldwide [4-8]. Specifically, $27 \%$ of coal reserves are threatened by water inrush disaster in China, and the economic loss due to water inrush in coal mining have reached 3 billion RMB since 1950 [9]. For a sustainable development of coal industry, it is essential to assess and reduce the risk of water inrush during coal mining.

In recent years, evaluation of water inrush from coal seam floor has become an active research topic and a large amount of literatures could be found [10, 11]. Dai et al. [12] evaluated the risk of water inrush from the floor of No. 11 coal seam at Hancheng mine, China using the GIS-based vulnerability index method. Their results showed that the accuracy of the risk assessment was found to be $82.35 \%$. The 
facts indicated that the method is effective for prevention and control of water inrush in the mine. Similarily, a GISbased analytic hierarchy process was proposed by Zeng et al. [13]. Eight control factors were determined to evaluate the water inrush of No. 10 coal seam in Wangjialing coal mine, China. Subsequently, the vulnerability zoning scheme for preventing water inrush was provided. For keeping coal mining safely in Chengzhuang mine, China, Li et al. [14] developed a set of methods including electromagnetic survey, drilling, water injection test, and numerical simulation to determine groundwater distribution, the aquifuge thickness, and the floor damage thickness. The results provided basic information for preventing water inrush. For assessing water inrush from coal seam floor, Wang et al. [15] setup a two-layer fuzzy comprehensive evaluation system with four indices in the first layer and thirteen indices in the second layer. The weight of every indice was determined by analytic hierarchy process. Application results were consistent with the engineering practice.

The previous studies mainly considered aquifuge thickness and water pressure on coal seam floor, which could not fully reflect the complex hydrogeological conditions of deep mining. Recently, horizontal directional drilling has been applied to detect fractures underneath coal beds, and cement grouting has been used to plug the pathway of water inrush in deep coal mining in China [16]. During the processes, more hydrogeological data could be collected than before. The aim of this study is to introduce a data fusion method based on grey system theory to assess the risk of water inrush in deep mining using the data collected from horizontal directional drilling and grouting engineering, and Xingdong Coal Mine, China was taken as an example to demonstrate the viability.

The grey system theory is fundamentally applicable to study the complex system in which information is partially known and partially unknown. Because of the complexity of geological structure and hydrogeological conditions in a deep coal mine, the groundwater flow system in a deep coal mine attribute a typical grey system. Grey system theory provides us ideal methods that could assimilate and fuse geological and hydrogeological data so as to reach a judgement about the risk of water inrush in deep coal mining. In this study, the data fusion method was built upon grey relational analysis and grey system evaluation, and it integrated the data of grouting quantity (the amount of grout consumed), the loss of drilling fluid, gamma value (a measure of porosity along the borehole), water temperature (an indicator of mixing of water from fractures in deep formations), average water absorption (a measure of formation storativity), distance between grouting loss points (distances between influential fractures), water pressure on coal seam floor, and aquifuge thickness at 90 boreholes in the mine to evaluate the risk of water inrush from the coal seam floor.

\section{Methods}

2.1. Grey Relational Analysis. Grey relational analysis is one of the grey system methods $[17,18]$, which has been widely applied in various fields, such as economics [19], sociology
[20], and environics [21]. Its basic idea is to determine the relational degree between two data sequences depending on the similarity of their geometric shapes. The closer the geometric shape between data sequences are, the larger the relational degree is [22].

Let the sequence of system behavior characteristics (i.e., grouting quantity) be $X_{0}(k)$ and the relational sequence be $X_{i}(k)$, the subscript $i=1,2, \ldots, m$ ( $m$ is 7$)$, representing the loss of drilling fluid, gamma value, water temperature, average water absorption, distance between grouting loss points, water pressure on coal seam floor, and aquifuge thickness, respectively. They are considered to be the major controlling factors. $k$ is the sample number and ranges from 1 to $n$. The $n$ is the total number of samples, which equals to 90 , i.e., the number of boreholes, in this case study.

To nondimensionalize the behavior characteristics sequence $X_{0}(k)$ and relational sequence $X_{i}(k)$, the following normalization operation were performed.

For the sequence of system behavior characteristics,

$$
\tilde{X}_{0}(k)=\frac{X_{0}(k)-\bar{X}_{0}(k)}{S_{0}(k)}, \quad k=1,2, \ldots, n,
$$

where

$$
\begin{aligned}
\bar{X}_{0}(k) & =\frac{1}{n} \sum_{k=1}^{n} X_{0}(k), \\
S_{0}(k) & =\sqrt{\frac{1}{n-1} \sum_{k=1}^{n}\left(X_{0}(k)-\bar{X}_{0}(k)\right)^{2} .}
\end{aligned}
$$

For the relational sequence,

$$
\tilde{X}_{i}(k)=\frac{X_{i}(k)-\bar{X}_{i}(k)}{S_{i}(k)}, \quad k=1,2, \ldots, n, i=1,2, \ldots, m,
$$

where

$$
\begin{aligned}
\bar{X}_{i}(k) & =\frac{1}{n} \sum_{k=1}^{n} X_{i}(k), \\
S_{i}(k) & =\sqrt{\frac{1}{n-1} \sum_{k=1}^{n}\left(X_{i}(k)-\bar{X}_{i}(k)\right)^{2} .}
\end{aligned}
$$

The absolute value sequence of the difference between the corresponding components of $\widetilde{X}_{0}(k)$ and $\widetilde{X}_{i}(k)$ is defined as

$$
\Delta_{i}(k)=\left|\widetilde{X}_{0}(k)-\widetilde{X}_{i}(k)\right|, \quad k=1,2, \ldots, n, i=1,2, \ldots, m .
$$

Then, the grey relational coefficient $\gamma_{X_{0} X_{i}}$ of $X_{0}(k)$ with respect to $X_{i}(k)$ can be calculated with the following formula: 


$$
\begin{array}{r}
\gamma_{X_{0} X_{i}}(k)=\frac{\Delta_{\min }+\xi \Delta_{\max }}{\Delta_{i}(k)+\xi \Delta_{\max }}, \quad \xi \in(0,1), \\
k=1,2, \ldots, n, \\
i=1,2, \ldots, m
\end{array}
$$

where $\Delta_{\max }=\max _{i} \max _{k} \Delta_{i}(k), \Delta_{\min }=\min _{i} \min _{k} \Delta_{i}(k)$, and $\xi$ is defined as a distinguishing coefficient, generally $\xi=0.5$.

Finally, we can acquire the grey relational degree $\Gamma_{X_{0} X_{i}}$ as defined below:

$$
\Gamma_{X_{0} X_{i}}=\frac{1}{n} \sum_{k=1}^{n} \gamma_{X_{0} X_{i}}(k), \quad k=1,2, \ldots, n, i=1,2, \ldots, m .
$$

In general, the influencing factors for $\Gamma_{X_{0} X_{i}}>0.70$ are defined as strong influencing factors. $0.60 \leq \Gamma_{X_{0} X_{i}} \leq 0.70$ are general or moderate, and $\Gamma_{X_{0} X_{i}}<0.60$ are weak [23].

2.2. Grey System Evaluation. Grey system evaluation is a method, based on whitenization weight functions of the grey number, to classify the controlling factors using their weights being determined [17, 18]. Total evaluation is performed based on calculation of comprehensive scores as described in the subsequent sections. This method has been widely used in the economy, environment, transportation, and other fields [24-26].

2.2.1. Whitenization Weight Function. In order to conduct the system evaluation, we calculated the mean, upper, and lower limits of each series $X_{i}(k)[22,27]$. They are

$$
\begin{aligned}
Z_{i} & =\bar{X}_{i}(k), \\
H_{i} & =\bar{X}_{i}(k)+S_{i}(k), \\
L_{i} & =\bar{X}_{i}(k)-S_{i}(k),
\end{aligned}
$$

where

$$
\begin{aligned}
\bar{X}_{i}(k) & =\frac{1}{n} \sum_{k=1}^{n} X_{i}(k), \\
S_{i}(k) & =\sqrt{\frac{1}{n-1} \sum_{k=1}^{n}\left(X_{i}(k)-\bar{X}_{i}(k)\right)^{2},} \\
k & =1,2, \ldots, n, \\
i & =1,2, \ldots, m .
\end{aligned}
$$

In the analysis of the risk of water inrush, the loss of drilling fluid, gamma value, average water absorption, and water pressure on the coal seam floor were treated as positive polarity controlling factors (i.e., the higher the values, the higher will be the risks), and the definition in equation (8) is used. On the other hand, water temperature, the distance between grouting loss points, and aquifuge thickness were considered to be negative polarity controlling factors (i.e., the lower the values are, the higher will be the risks). For this reason, the upper and lower limits for these controlling factors are defined as those in the following formula:

$$
\begin{aligned}
H_{i} & =\bar{X}_{i}(k)-S_{i}(k), \\
L_{i} & =\bar{X}_{i}(k)+S_{i}(k) .
\end{aligned}
$$

Afterward, we assigned the whitenization weights $f_{1 i}(k)$, $f_{2 i}(k)$, and $f_{3 i}(k)$ to each $X_{i}(k)$ series according to the formula (equations (11)-(13) or Figures 1-3, respectively) given below:

$$
\begin{aligned}
& f_{1 i}(k)= \begin{cases}1, & X_{i}(k) \leq L_{i}, \\
\frac{Z_{i}-X_{i}(k)}{Z_{i}-L_{i}}, & L_{i}<X_{i}(k)<Z_{i}, \\
0, & X_{i}(k) \geq Z_{i},\end{cases} \\
& f_{2 i}(k)= \begin{cases}0, & X_{i}(k) \geq H_{i}, \\
\frac{H_{i}-X_{i}(k)}{H_{i}-Z_{i}}, & Z_{i}<X_{i}(k)<H_{i}, \\
\frac{X_{i}(k)-L_{i}}{Z_{i}-L_{i}}, & X_{i}(k)=Z_{i}, \\
0 & L_{i}<X_{i}(k)<Z_{i},\end{cases} \\
& f_{3 i}(k)= \begin{cases}1, & X_{i}(k) \leq L_{i}, \\
\frac{X_{i}(k)-Z_{i}}{H_{i}-Z_{i}}, & Z_{i}<X_{i}(k)<H_{i}, \\
0, & X_{i}(k) \leq Z_{i} .\end{cases}
\end{aligned}
$$

2.2.2. Calculating the Weight Based on the Grey Relational Degree. According to the grey relational degree of each controlling factor, i.e., equation (7), we determined the weight of each controlling factor, $\Gamma_{i}$, with the following equation:

$$
w_{i}=\frac{\Gamma_{i}-0.7}{\sum_{i=1}^{m}\left(\Gamma_{i}-0.7\right)}, \quad i=1,2, \ldots, m
$$

2.2.3. Calculating the Comprehensive Scores. The comprehensive weight coefficient matrix was calculated with the following equation:

$$
\begin{array}{r}
A(k)=\left(\sum_{i=1}^{m} f_{1 i}(k) w_{i}, \sum_{i=1}^{m} f_{2 i}(k) w_{i}, \sum_{i=1}^{m} f_{3 i}(k) w_{i}\right), \\
i=1,2, \ldots, m, k=1,2, \ldots, n,
\end{array}
$$

where $f_{1 i}(k), f_{2 i}(k)$, and $f_{3 i}(k)$ are the whitenization weights determined previously.

Therefore, $\mathbf{A}$ is a $90 \times 3$ matrix. Then, we calculated the comprehensive risk scores of each sample location $k$ by 


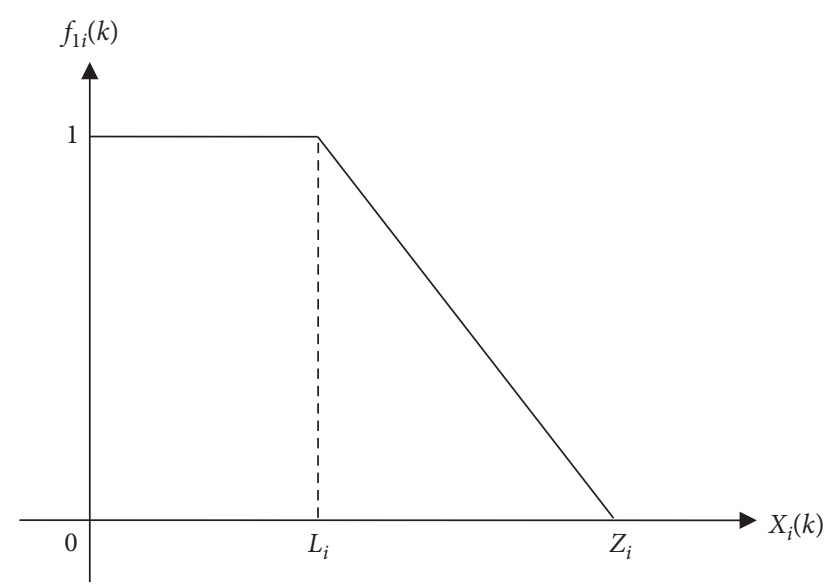

FIGURE 1: Whitenization weight function for $f_{1 i} k$.

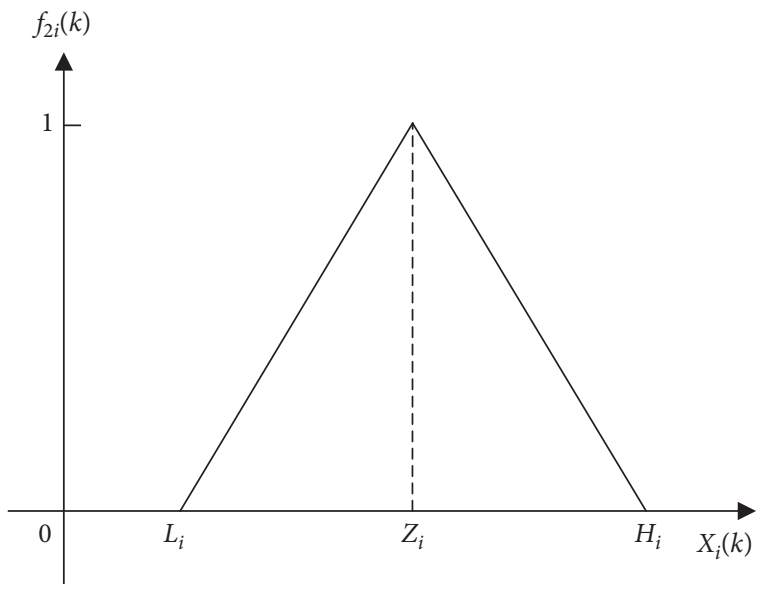

FIgURE 2: Whitenization weight function for $f_{2 i} k$.

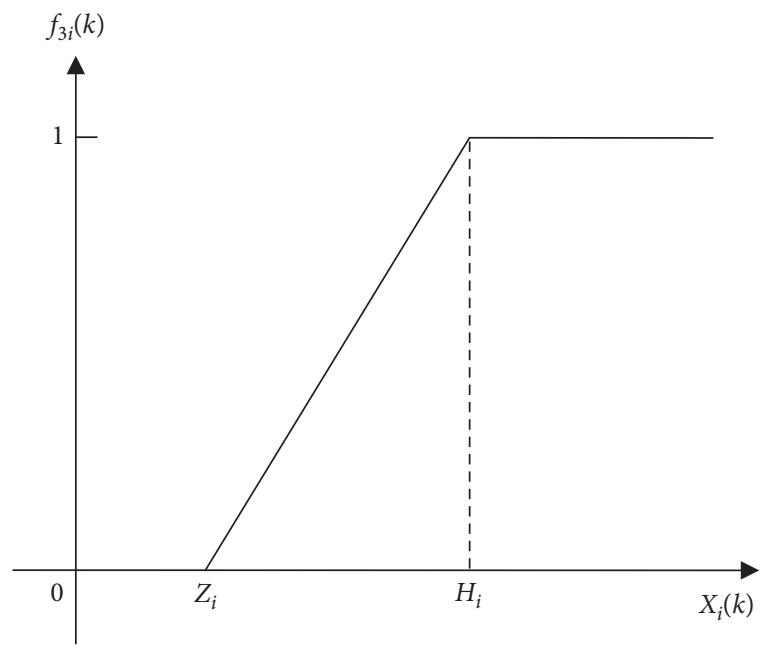

Figure 3: Whitenization weight function for $f_{3 i} k$.

$$
\mathbf{R}=\mathbf{A B} \times 200,
$$

where $\mathbf{B}=(0.2,0.3,0.5)^{T}$ is the normalized weight coefficient vector, $T$ denotes transpose, and $\mathbf{R}$ is a vector of $k$ $(1,2, \ldots, 90)$.
2.3. Procedures for the Assessment of Water Inrush Risks. The procedures for performing water inrush risks based on grey system theory using the data collected from grouting engineering practice are summarized and illustrated in the following Figure 4.

\section{The Generality of the Study Region}

3.1. Geographical Location of Xingdong Coal Mine. The Xingdong coal mine is located about $4 \mathrm{~km}$ northeast of Xingtai City, Hebei Province (Figure 5). The central geographical coordinates are $11430^{\prime} \mathrm{E}$ and $3705^{\prime} \mathrm{N}$. The shape of the study area, where mining working faces are deeper than $980 \mathrm{~m}$ below sea level, is an irregular rectangle with a size of $3.1 \mathrm{~km}$ long from north to south and $1 \mathrm{~km}$ wide from east to west. It is located at the west of the North China Plain. The ground elevation is 55-65 $\mathrm{m}$ above sea level (a.s.1.), and the terrain is high in the west and low in the east $[16,28]$.

3.2. Hydrogeological Condition of Xingdong Coal Mine. The geological strata in the area include Cambrian, Ordovician, Carboniferous, Permian, Triassic, and Quaternary formations. The Carboniferous and Permian strata are the main coal-bearing formations (Figure 6). The average thickness of coal-bearing strata is $217.13 \mathrm{~m}$, and there are 15 layers of coal seams in total. Faults developed in the area, mainly NNE-NE normal faults and a few NW normal faults (Figures 5 and 6).

The main aquifers in the Xingdong coal mine are upperfractured Triassic sandstone aquifer and lower-fractured Ordovician limestone karst aquifer. The fractured sandstone aquifer in the upper part of the Xingdong coal mine is of low water storage capacity and mainly contains stagnant groundwater (isolated reservoirs), as evident by a large amount of discharge initially, and decreasing or cease of discharge after a period of time of the outburst. The limestone fracture aquifer in the lower part is considered that it contains a small to a large amount of groundwater. The water level is $25.35 \sim 35.95 \mathrm{~m}$ a.s.l., which is above the $2^{\#}$ coal seam (550 1100 m below sea level) that is currently being mined. There are 5 layers of aquicludes between $2^{\#}$ coal seam and the top of the Ordovician limestone. The limestone water enters the mine mainly through faults or collapsed columns, which is a major threat to coal mining. Precipitation infiltrates directly through the exposed limestone area in the western mountainous area and forms a planar recharge. In the rainy season and flood season, the aquifer is recharged by the Nanming River, Beiming River, Mahui River, Sha River, Qili River, Baima River, and other rivers.

3.3. Analysis of Ordovician Limestone Karst Fissure Aquifer. The Ordovician limestone, with a thickness of $447.80 \sim 639.20 \mathrm{~m}$, is a set of marine carbonate strata. According to its lithological characteristics, sedimentary cycle, and hydrogeological characteristics, this limestone formation can be divided into three groups and eight sections: Fengfeng Formation (7 and 8 sections), Shangmajiagou Formation (4, 5, and 6 sections), and Xiamajiagou 


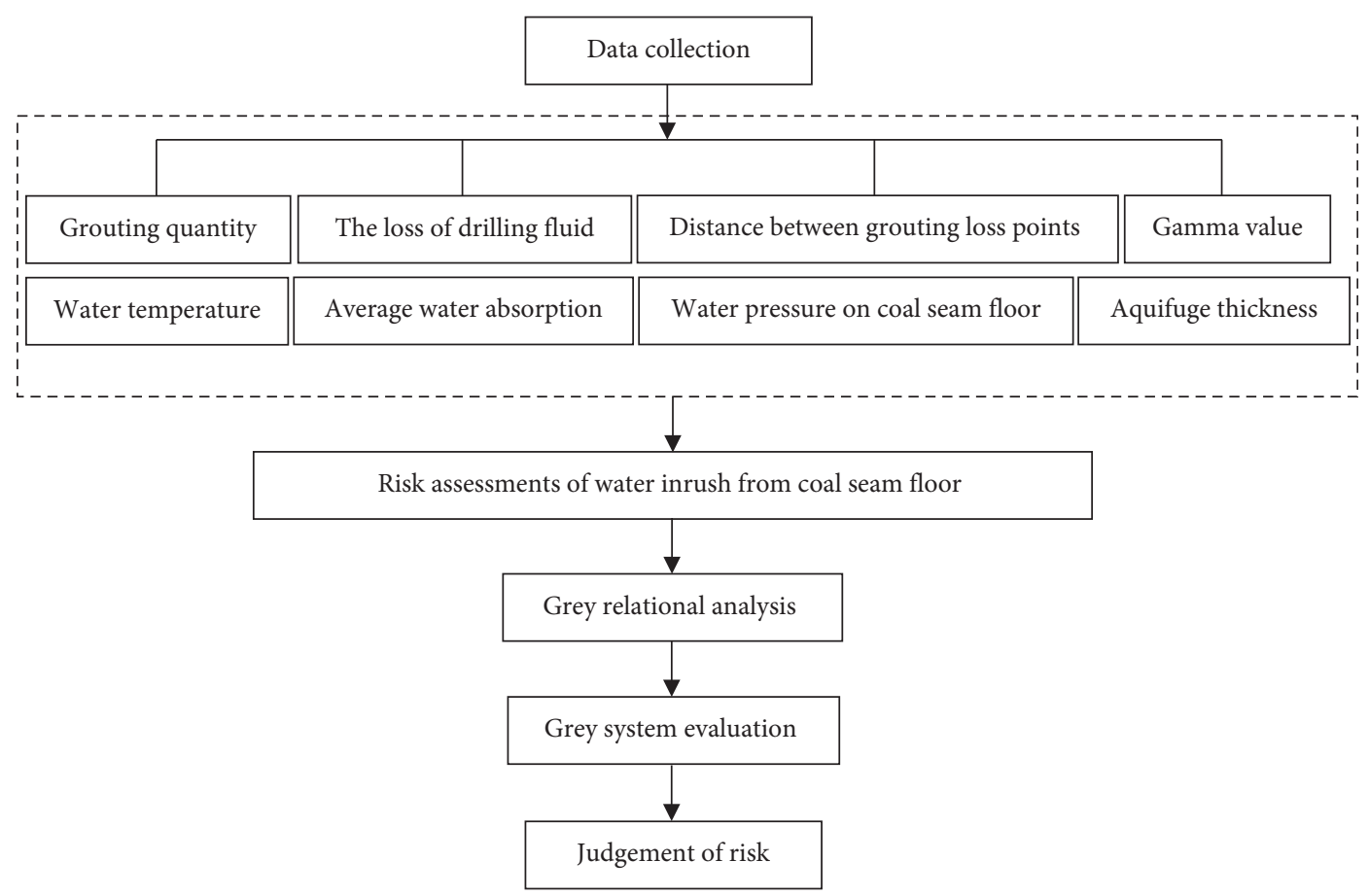

FIGURE 4: The flowchart of risk assessment based on grey system theory for deep coal mining.

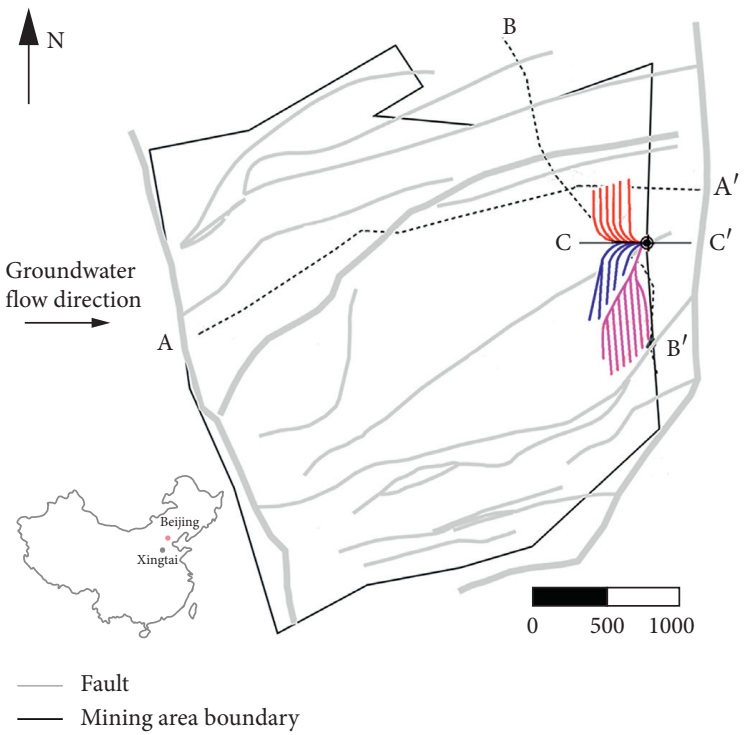

FIgUre 5: Location of the Xingdong coal mine in China.

Formation (1, 2, and 3 sections). Due to the differences in chemical composition, structure, lithologic characteristics, and fracture development, the hydraulic characteristics in each group are different. Among them, the middle and upper parts of the aquifer are medium-thick limestone formations, with developed karst fissures and abundant groundwater, constituting a relatively uniform water-bearing body. Due to the directionality and heterogeneity of structure and fracture development, the karst fissure aquifer enriched with water in Ordovician limestone is considered highly heterogeneous.

As mentioned previously, the Ordovician limestone aquifer has localized recharge away from the mine. Its main recharge period is July to September every year. At present, the water level of Ordovician limestone aquifer in the region is generally around $30 \sim 60 \mathrm{~m}$ a.s.l.

3.4. Grouting Engineering Design. Grouting is a technology that uses a high-pressure grouting pump to inject cement and other grouts into the voids occurred in a stratum through drilling holes to block the water source channel and enhance the stratum strength or water insulation performance $[29,30]$. For the layout of boreholes, we considered working face distribution, regional hydrogeological conditions, and 

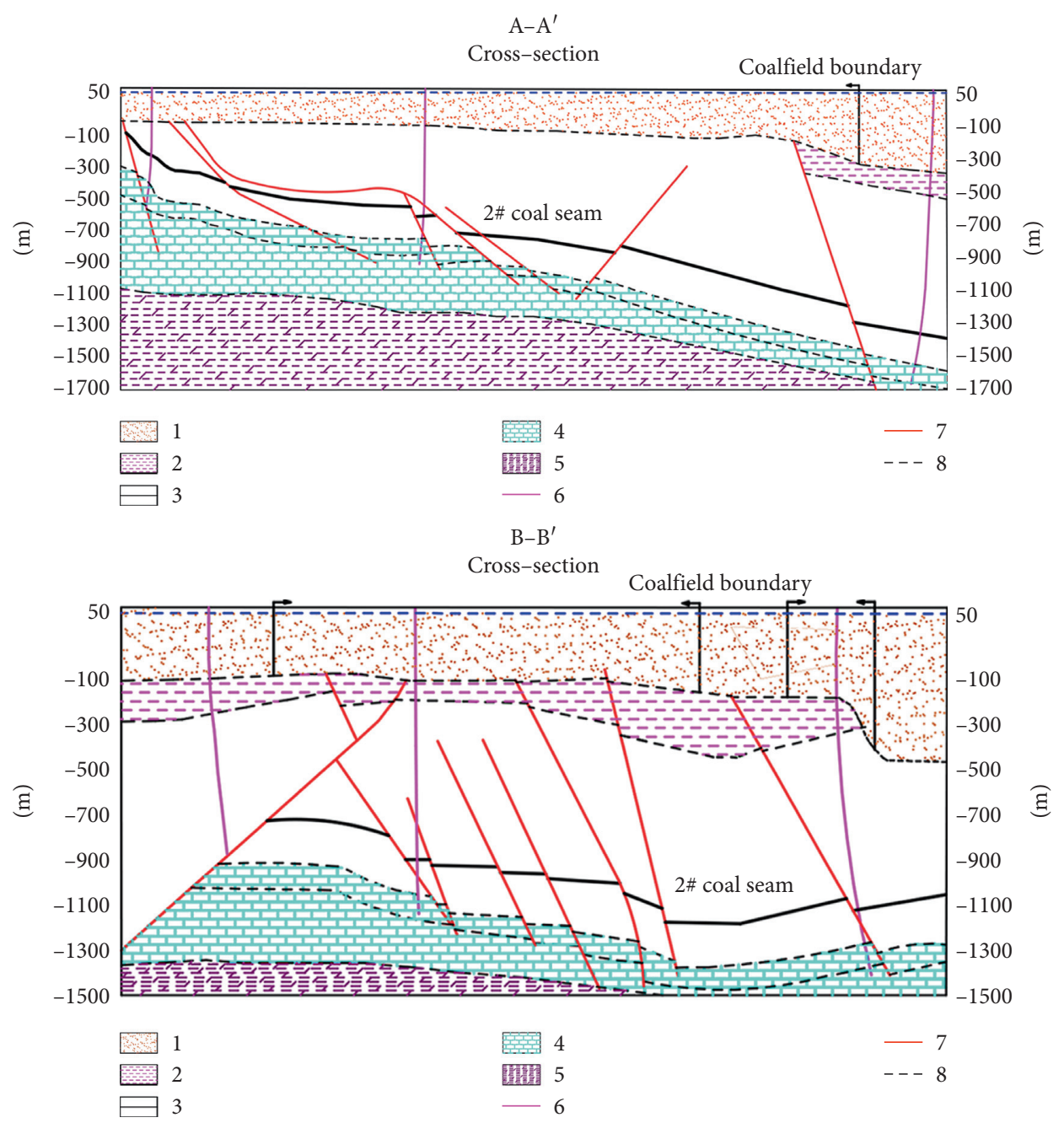

Figure 6: Geological cross-sections corresponding to A-A' and B-B' in Figure 5. 1. Quaternary deposit; 2. Triassic sandstone; 3. Carboniferous and Permian coal seam; 4. Ordovician limestone; 5. Cambrian dolomite rock; 6. Well track; 7. Fault; 8. Boundary.

geological characteristics of the targeted layer to be grouted. The layout was designed so that the branch of boreholes could cover the whole working area and intersect with dominant fault planes.

The engineering operation in the Xingdong coal mine area at $980 \mathrm{~m}$ below sea level adopted the technology of horizontally branching borehole groups to penetrate the possible water-carrying structure and Ordovician limestone aquifer in the area to the maximum extent. Through the grouting engineering, the passage of Ordovician limestone water into the mine was blocked, and the safety of deep mining face was ensured.

The operation installed one borehole on the ground, denoted as XD1 in Figure 7. Then, a series of nearly horizontal boreholes were drilled into the Ordovician limestone with the distance between every two boreholes about $70 \mathrm{~m}$ (Figure 7). In the north area, 17 nearly horizontal boreholes were arranged, numbered N1 N14, N4t, N4t-1, and N6t. In the south area, 9 horizontal boreholes were installed, numbered S1 S9. In 2129 mining face, 14 horizontal boreholes were implemented, numbered
T1 T14. The accumulated drilling distance was $27638.98 \mathrm{~m}$. In Figure 7, different colors of the nearly horizontal boreholes represent different stages of grouting. The main mining faces are 2125, 2126, 2127, 2129, 2222, 2224, and 2228. Their locations are shown in Figure 8.

Using a high-pressure grouting pump, grouts were mainly injected to the lower part of the 8th section of the Ordovician limestone. Cement and water with a mass ratio $1: 3$ was mixed for injection. A total of 98 grouting operations were conducted and 21428.36 tons of cements were injected.

3.5. Data Acquisition. In the grouting process from the directional boreholes, we obtained the data of grouting quantity, the loss of drilling fluid, gamma value, water temperature, average water absorption, distance between grouting loss points, water pressure on coal seam floor, and aquifuge thickness at 90 boreholes in the Xingdong coal mine. The standardized data are summarized in the appendix (i.e., Table 1). 


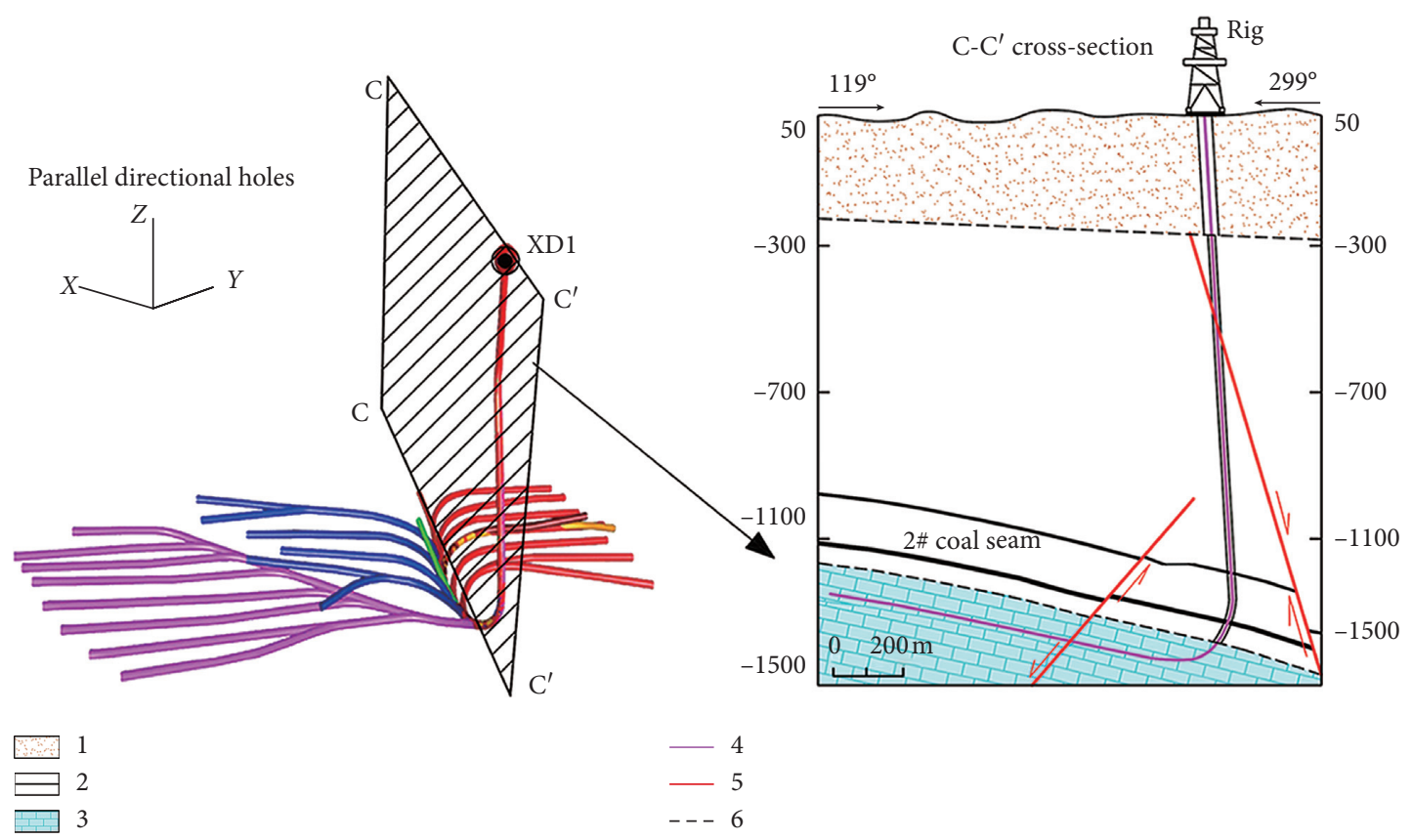

Figure 7: The profile of directional holes and geological cross-section corresponding to C-C' in Figure 5.

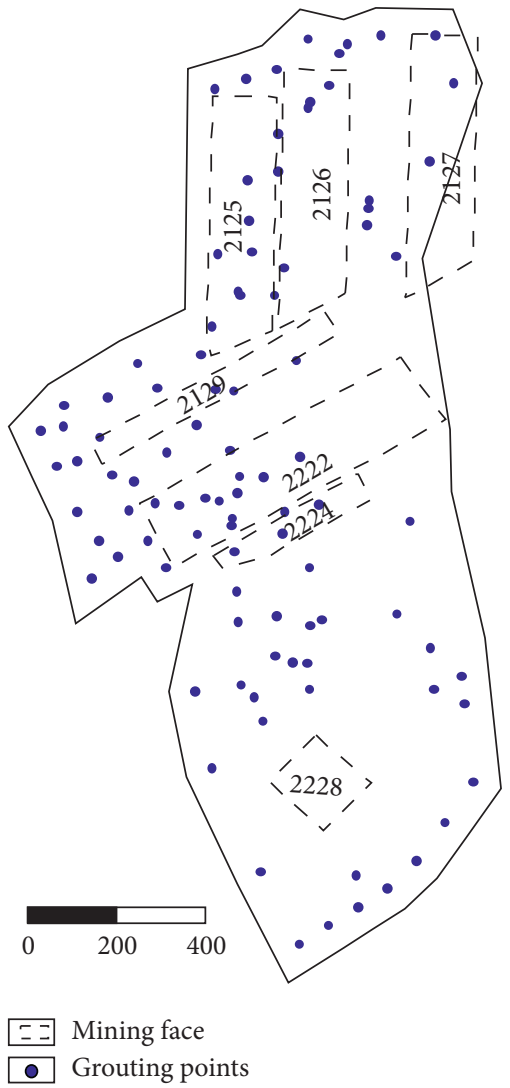

FIGURE 8: Location of mining faces and grouting points.

\section{Results}

4.1. Grey Relational Degrees. Using the data collected and equations (6) and (7), we calculated the grey relational degrees at 90 boreholes (Table 2). In the equations, the data of grouting quantity were $X_{0}(k)(k=1,2, \ldots, 90)$, which represents the system behavior characteristics (i.e., the risk of water inrush). In the Xingdong coal mine, water inrush is caused by the high-pressure groundwater in Ordovician carbonate formation underneath the coal seam bed that gushes into the coal mine through fractures and faults. The more fractures and faults exist, the higher risk of water inrush is. On the other hand, more fractures and faults require larger grouting quantity in grouting engineering. Therefore, the grouting quantity could be used to represent water inrush risk. The data of the loss of drilling fluid, gamma value, water temperature, average water absorption, distance between grouting loss points, water pressure on the coal seam floor, and aquifuge thickness were designated as $X_{i}(k),(k=1,2, \ldots, 90 ; i=1,2, \ldots, 7)$, which were collected during detecting fractures and grouting processes. The seven hydrogeological factors are related to grouting quantity and selected as the main controlling factors. The purpose of grey relational analysis was to find the correlations between the grouting quantity and the seven relational factors. The factors with larger grey relational degrees should be endowed bigger weights in grey evaluation.

Grey relational degrees of the seven factors were all larger than 0.70 , which indicates that all seven controlling factors are significantly influencing the grouting quantity. Such a result also shows that the controlling factors we selected are appropriate. Thus, the weights can be determined according to their grey relational degrees.

4.2. Grey System Evaluation. Afterward, we used equations (8) and (10) to determine the grey boundaries $\left(H_{i}, Z_{i}\right.$, and $\left.L_{i}\right)$ of each controlling factor, as shown in Table 3 . 
TABLE 1: The standardized data of 90 boreholes in the Xingdong coal mine.

\begin{tabular}{|c|c|c|c|c|c|c|c|c|}
\hline Number & $\begin{array}{l}\text { Grouting } \\
\text { quantity }\end{array}$ & $\begin{array}{l}\text { The loss of } \\
\text { drilling fluid }\end{array}$ & $\begin{array}{l}\text { Gamma } \\
\text { value }\end{array}$ & $\begin{array}{c}\text { Water } \\
\text { temperature }\end{array}$ & $\begin{array}{c}\text { Average water } \\
\text { absorption }\end{array}$ & $\begin{array}{l}\text { Distance between } \\
\text { grouting loss points }\end{array}$ & $\begin{array}{c}\text { Water pressure on } \\
\text { coal seam floor }\end{array}$ & $\begin{array}{l}\text { Aquifuge } \\
\text { thickness }\end{array}$ \\
\hline 1 & -0.54183 & 2.16865 & 2.02169 & -0.38663 & 0.11031 & 0.39485 & 0.23990 & -0.56348 \\
\hline 2 & -0.92586 & -0.61143 & -0.41653 & -0.33470 & -0.29407 & -0.51084 & 0.43328 & -0.56348 \\
\hline 3 & 5.63370 & -0.40396 & -1.02608 & -0.44835 & -0.77155 & -0.29206 & 0.46171 & -0.56348 \\
\hline 4 & -1.35491 & -0.61143 & -1.02608 & -0.13679 & -0.18998 & -0.59231 & 0.79848 & -0.56348 \\
\hline 5 & -0.42055 & -0.40396 & 0.80258 & -0.41112 & 0.15371 & 1.08772 & -0.01020 & -0.56348 \\
\hline 6 & 0.31359 & 0.01097 & 0.19303 & -0.48754 & -1.15765 & 6.79351 & -0.01459 & -0.56348 \\
\hline 7 & -0.68751 & -0.44546 & 0.80258 & -0.33470 & -0.69616 & -0.06347 & -0.05016 & -0.56348 \\
\hline 8 & 0.00849 & 0.67487 & 1.41213 & -0.44247 & 0.46442 & -0.45904 & 0.35459 & -0.56348 \\
\hline 9 & 0.24685 & -0.32098 & 1.41213 & -0.22693 & 0.97160 & -0.16546 & -0.39228 & 0.91074 \\
\hline 10 & -0.70658 & -0.52845 & 0.19303 & -0.02902 & -1.09368 & 1.76884 & -0.44955 & 0.91074 \\
\hline 11 & 0.09430 & -0.52015 & 2.63124 & 0.11892 & -0.93376 & 0.35218 & -0.58923 & 0.91074 \\
\hline 12 & -0.43962 & 2.16865 & 2.63124 & -0.27984 & -1.13480 & 4.35928 & -0.53581 & 0.91074 \\
\hline 13 & -0.75425 & -0.63218 & 0.19303 & -0.23967 & 0.57755 & -0.46256 & -1.09218 & 0.91074 \\
\hline 14 & -0.70658 & -0.48695 & 2.63124 & -0.11916 & -0.72403 & 0.05828 & -0.66436 & 0.91074 \\
\hline 15 & 0.48520 & 2.16865 & 0.19303 & -0.44247 & -0.79165 & 0.17921 & -0.72822 & 0.91074 \\
\hline 16 & -0.61123 & -0.07201 & 0.19303 & -0.06821 & -0.89263 & 0.45449 & -0.39393 & 0.91074 \\
\hline 17 & -0.37288 & -0.32098 & 0.80258 & -0.32882 & -0.54172 & -0.13422 & -0.52578 & 0.91074 \\
\hline 18 & 0.24685 & -0.32098 & 0.19303 & -0.24848 & 1.32731 & -0.52992 & 0.04350 & 0.91074 \\
\hline 19 & 0.05616 & -0.02222 & 0.19303 & -0.22693 & -0.98077 & 0.86010 & 0.02126 & 0.91074 \\
\hline 20 & -0.56356 & -0.56994 & 0.19303 & -0.03294 & -0.34232 & -0.26289 & -0.00031 & 0.91074 \\
\hline 21 & 0.38986 & -0.07201 & 0.19303 & -0.41210 & 1.06299 & -0.51676 & 0.61581 & 0.91074 \\
\hline 22 & -0.70658 & -0.61143 & 0.80258 & -0.25044 & -0.53167 & -0.26213 & 0.36681 & 0.91074 \\
\hline 23 & -0.51589 & -0.61143 & 0.19303 & -0.43365 & 0.27343 & 0.27781 & 0.48534 & 0.91074 \\
\hline 24 & 0.22778 & -0.32098 & 0.19303 & -0.54045 & 0.10181 & -0.41239 & 1.42174 & -0.56348 \\
\hline 25 & -0.60170 & -0.41226 & -1.63564 & -0.15933 & 1.22748 & -0.52409 & -0.35932 & 0.91074 \\
\hline 26 & -0.56356 & -0.52015 & -2.24519 & -0.51105 & -0.46276 & -0.19003 & -0.50394 & 0.91074 \\
\hline 27 & -0.22986 & -0.52845 & -1.63564 & 2.46441 & 1.83061 & -0.55334 & 0.65523 & -0.56348 \\
\hline 28 & -0.82099 & -0.61143 & 0.19303 & 3.35891 & -0.44942 & -0.56066 & 0.19774 & -0.56348 \\
\hline 29 & 0.24685 & -0.40396 & 0.19303 & -0.55024 & 0.09431 & -0.40746 & 1.28838 & -0.56348 \\
\hline 30 & -1.02121 & -0.61143 & 0.19303 & -0.31217 & -0.48597 & -0.47801 & 0.81968 & -0.56348 \\
\hline 31 & 0.81890 & -0.61143 & -0.41653 & 4.66001 & 0.70202 & -0.51289 & -0.06335 & -0.56348 \\
\hline 32 & -0.08685 & 2.16865 & 0.49780 & 0.20318 & 0.44157 & -0.46553 & 1.27052 & -0.56348 \\
\hline 33 & 0.38986 & -0.32098 & 0.19303 & -0.44247 & -0.98402 & 0.81701 & 1.31612 & -0.56348 \\
\hline 34 & -0.22986 & -0.23799 & -0.41653 & -0.55024 & -1.09825 & 2.42884 & 1.24360 & -0.56348 \\
\hline 35 & -0.22033 & -0.44546 & -1.63564 & -0.55024 & 0.45848 & -0.46553 & 1.79421 & -0.56348 \\
\hline 36 & -0.62077 & -0.61143 & 0.19303 & -0.65801 & 1.49341 & -0.54277 & 2.00709 & -0.56348 \\
\hline 37 & 0.10383 & -0.52015 & -0.41653 & -0.14757 & 2.51599 & -0.57529 & 2.11477 & -1.44801 \\
\hline 38 & 0.62822 & -0.40396 & -1.02608 & -0.33470 & -0.72357 & -0.00414 & 1.93251 & -1.44801 \\
\hline 39 & -0.52543 & -0.66952 & -1.02608 & 6.12080 & 0.10556 & -0.41472 & 1.41720 & -1.44801 \\
\hline 40 & 0.24685 & 2.16865 & -1.02608 & -0.33470 & 0.70659 & -0.49602 & 2.27944 & -1.44801 \\
\hline 41 & 0.92378 & -0.19650 & -1.63564 & -0.34156 & -0.91091 & 0.40237 & 2.19319 & -1.44801 \\
\hline 42 & 4.20356 & -0.67367 & 0.80258 & 0.20318 & -0.55908 & -0.27370 & 1.95133 & -1.44801 \\
\hline 43 & 3.20247 & -0.42056 & -0.41653 & -0.39936 & 4.38937 & -0.59968 & 0.07839 & -1.44801 \\
\hline 44 & 1.67699 & -0.47035 & 0.19303 & 0.16105 & 2.95464 & -0.57935 & -0.14452 & -1.44801 \\
\hline 45 & 0.10383 & -0.80230 & -1.02608 & 0.00919 & -0.90634 & 0.53246 & -0.42195 & -1.44801 \\
\hline 46 & -0.64937 & -0.48695 & 2.02169 & -0.31413 & -0.33519 & -0.29480 & 0.90725 & -1.44801 \\
\hline 47 & -0.37288 & -0.48695 & 2.02169 & -0.22693 & -0.81039 & 0.18895 & 0.80644 & -1.44801 \\
\hline 48 & 0.19918 & 2.16865 & -0.41653 & -0.20929 & -0.97031 & 0.80888 & 0.71360 & -1.44801 \\
\hline 49 & 0.73310 & 0.17695 & 0.19303 & -0.33470 & 1.30515 & -0.52041 & -0.66999 & -1.44801 \\
\hline 50 & 0.43753 & 2.16865 & 0.19303 & 0.05719 & -0.60345 & -0.10374 & 0.62611 & -1.44801 \\
\hline 51 & -0.54449 & -0.56994 & 0.19303 & 0.67737 & 1.75751 & -0.55293 & -0.49227 & -1.44801 \\
\hline 52 & -0.75425 & -0.52015 & 0.19303 & 0.17868 & -0.36717 & -0.25211 & 0.23070 & -1.44801 \\
\hline 53 & 0.62822 & -0.61973 & 0.19303 & 1.49447 & 0.34334 & -0.47122 & -0.64980 & -1.44801 \\
\hline 54 & -0.46822 & -0.02222 & 0.19303 & 0.86842 & 0.08061 & -0.42447 & 2.07603 & -1.44801 \\
\hline 55 & -0.27754 & -0.25459 & 2.02169 & 0.05915 & 1.35907 & -0.53210 & 0.78117 & -1.44801 \\
\hline 56 & -1.08795 & -0.23799 & -0.41653 & -0.14953 & 2.42918 & -0.56919 & 0.51624 & -1.44801 \\
\hline 57 & -0.61123 & -0.71932 & -0.41653 & 0.11990 & -0.32514 & -0.25821 & -0.34586 & -1.44801 \\
\hline 58 & -0.40148 & -0.32098 & -1.02608 & -0.48852 & -0.46770 & -0.22630 & 0.62776 & -0.56348 \\
\hline 59 & 0.96192 & -0.60313 & -0.41653 & -0.02804 & -0.09302 & -0.43222 & 0.08224 & -0.56348 \\
\hline
\end{tabular}


TABle 1: Continued.

\begin{tabular}{|c|c|c|c|c|c|c|c|c|}
\hline Number & $\begin{array}{l}\text { Grouting } \\
\text { quantity }\end{array}$ & $\begin{array}{l}\text { The loss of } \\
\text { drilling fluid }\end{array}$ & $\begin{array}{l}\text { Gamma } \\
\text { value }\end{array}$ & $\begin{array}{c}\text { Water } \\
\text { temperature }\end{array}$ & $\begin{array}{c}\text { Average water } \\
\text { absorption }\end{array}$ & $\begin{array}{c}\text { Distance between } \\
\text { grouting loss points }\end{array}$ & $\begin{array}{c}\text { Water pressure on } \\
\text { coal seam floor }\end{array}$ & $\begin{array}{l}\text { Aquifuge } \\
\text { thickness } \\
\end{array}$ \\
\hline 60 & -0.39614 & -0.66952 & -0.41653 & 0.32662 & -0.45399 & -0.27420 & 1.16834 & -0.56348 \\
\hline 61 & -0.61123 & -0.07201 & -1.02608 & 0.74791 & 0.83910 & -0.50008 & 0.82333 & 0.91074 \\
\hline 62 & 0.28499 & 2.16865 & -0.41653 & -0.24848 & 0.29993 & -0.43098 & -1.04535 & 0.91074 \\
\hline 63 & -0.67797 & -0.37077 & 0.19303 & 0.03858 & -0.68245 & 0.01822 & -0.70130 & 0.91074 \\
\hline 64 & 1.02866 & -0.71932 & -0.41653 & -0.28277 & -0.78754 & 0.19912 & -1.18392 & 0.91074 \\
\hline 65 & -0.58263 & -0.76911 & 0.19303 & 0.19828 & -0.01439 & -0.42895 & -0.91102 & 0.91074 \\
\hline 66 & 0.00849 & -0.32098 & -2.85474 & -0.34646 & -0.27808 & -0.27447 & -0.67754 & 0.91074 \\
\hline 67 & 0.10383 & -0.32098 & -1.02608 & 0.35504 & -0.44714 & -0.17894 & -0.97310 & 0.91074 \\
\hline 68 & -0.68751 & -0.79401 & -0.41653 & -0.38369 & -0.85311 & 0.18692 & -1.39062 & 0.91074 \\
\hline 69 & -0.69704 & -0.37077 & -1.02608 & -0.47284 & -0.59107 & -0.10170 & -0.44667 & 0.91074 \\
\hline 70 & -0.02965 & 2.16865 & -1.02608 & -0.28963 & -0.04276 & -0.35984 & -0.79030 & 0.91074 \\
\hline 71 & -0.15359 & -0.80230 & 0.19303 & -0.24750 & -0.81267 & 0.23570 & -0.88246 & 0.91074 \\
\hline 72 & -0.70658 & -0.32098 & 0.19303 & -0.44247 & -0.10216 & -0.34561 & -0.66765 & 0.91074 \\
\hline 73 & -0.61123 & 0.27653 & -1.02608 & -0.22791 & -0.34890 & -0.24601 & -0.54308 & 0.91074 \\
\hline 74 & 0.13244 & -0.47035 & -1.02608 & -0.37291 & -0.53624 & -0.12467 & -0.94124 & 0.91074 \\
\hline 75 & -0.30614 & -0.07201 & -1.02608 & -0.33470 & 1.70724 & -0.54480 & -0.61588 & 0.91074 \\
\hline 76 & -0.15359 & 2.16865 & 0.19303 & -0.39153 & 0.38217 & -0.43098 & -1.24023 & 0.91074 \\
\hline 77 & -0.56356 & -0.71932 & 0.19303 & -0.11524 & -0.96117 & 0.57514 & -1.32305 & 0.91074 \\
\hline 78 & 0.59962 & 2.16865 & 0.19303 & -0.55024 & -0.66477 & 0.01822 & -1.25534 & 0.91074 \\
\hline 79 & -0.53496 & -0.80230 & 1.41213 & -0.52183 & -0.36658 & -0.21349 & -1.51492 & 0.91074 \\
\hline 80 & -1.13562 & -0.80230 & 0.19303 & -0.22693 & -0.12044 & -0.52854 & -1.51355 & 0.91074 \\
\hline 81 & 0.24685 & 2.16865 & 0.19303 & -0.38467 & -0.07931 & -0.33545 & -1.21016 & 0.91074 \\
\hline 82 & 1.29562 & 2.16865 & 0.19303 & -0.41504 & -0.89720 & 0.54872 & -1.34860 & 0.91074 \\
\hline 83 & 0.38033 & -0.22139 & 0.19303 & -0.34842 & -0.70073 & 0.08529 & -1.58483 & 0.91074 \\
\hline 84 & -0.02011 & -0.32098 & -1.02608 & -0.55024 & -0.07246 & -0.33748 & -1.03587 & 0.91074 \\
\hline 85 & 0.18964 & 2.16865 & 0.19303 & -0.36409 & -0.66189 & 0.01822 & -1.25273 & 0.91074 \\
\hline 86 & 0.24685 & -0.52015 & 0.19303 & -0.44345 & -0.79896 & 0.25806 & -1.37758 & 0.91074 \\
\hline 87 & 0.15151 & 2.16865 & 0.19303 & 0.15027 & 0.04862 & -0.38220 & -0.58717 & 0.91074 \\
\hline 88 & -0.10592 & -0.61973 & 0.19303 & -0.44247 & -0.65960 & -0.00821 & -0.75212 & 0.91074 \\
\hline 89 & -0.37288 & -0.66952 & 0.19303 & -0.31707 & 0.23139 & -0.42691 & 0.02194 & 0.91074 \\
\hline 90 & -0.13452 & -0.71932 & 0.19303 & 0.05328 & 0.81625 & -0.48992 & -0.31908 & 0.91074 \\
\hline
\end{tabular}

TABLE 2: The results of grey relational degrees.

\begin{tabular}{lccccccc}
\hline Related factors & $\begin{array}{c}\text { Average water } \\
\text { absorption }\end{array}$ & $\begin{array}{c}\text { Gamma } \\
\text { value }\end{array}$ & $\begin{array}{c}\text { The loss of } \\
\text { drilling fluid }\end{array}$ & $\begin{array}{c}\text { Distance between } \\
\text { grouting loss points }\end{array}$ & $\begin{array}{c}\text { Water } \\
\text { temperature }\end{array}$ & $\begin{array}{c}\text { Water pressure on } \\
\text { coal seam floor }\end{array}$ & $\begin{array}{c}\text { Aquifuge } \\
\text { thickness }\end{array}$ \\
\hline Grey relational degree & 0.8396 & 0.8342 & 0.8306 & 0.8165 & 0.7907 & 0.7850 & 0.7619 \\
\hline
\end{tabular}

TABLE 3: The class limits of each controlling factor.

\begin{tabular}{|c|c|c|c|c|c|c|c|}
\hline \multirow{2}{*}{$\begin{array}{l}\text { Upper, mean, } \\
\text { and lower limits }\end{array}$} & \multicolumn{7}{|c|}{ Controlling factors } \\
\hline & $\begin{array}{l}\text { The loss of } \\
\text { drilling fluid }\end{array}$ & $\begin{array}{l}\text { Gamma } \\
\text { value }\end{array}$ & $\begin{array}{c}\text { Average } \\
\text { water absorption }\end{array}$ & $\begin{array}{c}\text { Water pressure on } \\
\text { coal seam floor }\end{array}$ & $\begin{array}{c}\text { Water } \\
\text { temperature }\end{array}$ & $\begin{array}{l}\text { Distance between } \\
\text { grouting loss points }\end{array}$ & $\begin{array}{l}\text { Aquifuge } \\
\text { thickness }\end{array}$ \\
\hline$H_{i}$ & 32.45 & 11.98 & 0.0057 & 13.62 & 28.04 & 44.5 & 173.52 \\
\hline$Z_{i}$ & 20.36 & 6.88 & 0.0032 & 12.91 & 29.68 & 263.36 & 176.91 \\
\hline$L_{i}$ & 8.26 & 1.77 & 0.0008 & 12.2 & 31.32 & 482.22 & 180.3 \\
\hline
\end{tabular}

After calculating the whitenization weight function using equations (11)-(13), the weight of each controlling factor was then calculated with equation (14) (Table 4).

Finally, the comprehensive weight coefficient matrix was calculated using equation (15), and the comprehensive risk scores were obtained from equation (16). The contours of the risk in centesimal scores are displayed in Figure 9 to show water inrush risk across the mining area. This risk of water inrush is expressed in centesimal score. The larger the score, the higher will be the risk. When the score is larger than 60, the risk of water inrush can be considered as high. 
TABLE 4: The weight of each controlling factor.

\begin{tabular}{lccccccc}
\hline $\begin{array}{l}\text { Controlling } \\
\text { factor }\end{array}$ & $\begin{array}{c}\text { Average water } \\
\text { absorption }\end{array}$ & $\begin{array}{c}\text { Gamma } \\
\text { value }\end{array}$ & $\begin{array}{c}\text { The loss of } \\
\text { drilling fluid }\end{array}$ & $\begin{array}{c}\text { Distance between } \\
\text { grouting loss points }\end{array}$ & $\begin{array}{c}\text { Water } \\
\text { temperature }\end{array}$ & $\begin{array}{c}\text { Water pressure } \\
\text { on coal seam floor }\end{array}$ & $\begin{array}{c}\text { Aquifuge } \\
\text { thickness }\end{array}$ \\
\hline Weight & 0.184 & 0.177 & 0.172 & 0.154 & 0.120 & 0.112 & 0.081 \\
\hline
\end{tabular}

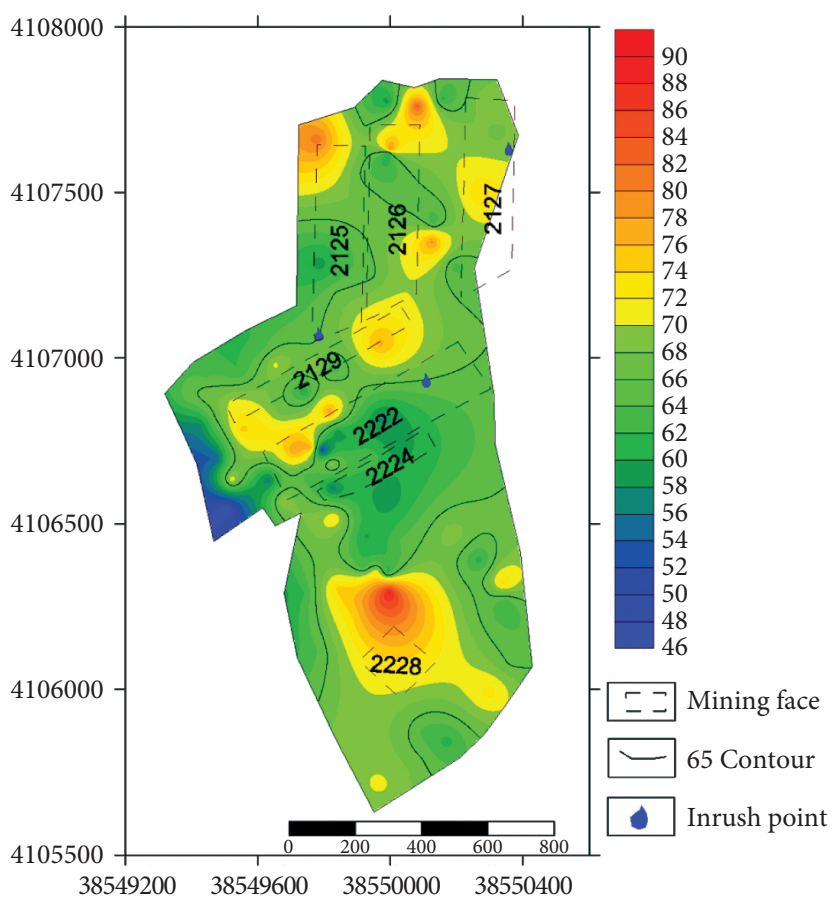

Figure 9: The contour of water inrush risk.

\section{Discussion}

The water inrush is mainly caused by high-pressure groundwater gushing through fractures and faults connected between the coal seam bed and underneath Ordovician carbonate rock formation in the Xingdong coal mine. For the safety during coal mining, the effective preliminary works are to detect the fractures and faults potentially deliver high-pressure karst groundwater to the coal mine and then to plug the pathways. Simultaneously, we also want to quantitatively assess the risk of water inrush for the coal seam areas. In recent years, the horizontal directional drilling has been used to detect the fractures and faults connected between the coal seam bed and underneath karst formation. During the drilling and grouting processes, one can collect much more data reflecting hydrological conditions, which make it possible to assess the water inrush risk from more aspects using the data fusion method.

Table 2 showed that the primary three controlling factors affecting water inrush were average water absorption, gamma value, and loss of drilling fluid, which reflect the formation storativity, porosity, and fractures and karst developed in the carbonate rock underneath the coal seam, respectively. The results indicated that the hydrogeological structure of carbonate formation under the coal seam dominated the water inrush. Accordingly, higher weights were assigned to the three factors compared with other four factors (Table 4).
According to Figure 9, water inrush risk of the coal seam floor in the Xingdong coal mine can be divided into three levels: the red color area denotes the high-risk area, the blue color area represents the low-risk area, and the green and yellow color areas stand for the moderate-risk area.

During the previous operation of the Xingdong coal mine in the deep mining area at $980 \mathrm{~m}$ below sea level, three water inrushes from the Ordovician limestone occurred in mining face 2127, 2125, and 2222 (Table 5). As can be seen from Figure 9, all the three water inrush points were located in the area with a risk score higher than 65 . Based on the observation data of various aspects of water inrush, it was concluded that the water inrush from the mining face 2127 and 2222 was the water from the coal seam floor, and the water inrush of 2125 mining face was caused by the advanced drilling hole in the floor. Nevertheless, the grouting process effectively blocked the identified cracks, formed floor water-proof layers for the three mining faces, and reduced the threat of water inrush from the Ordovician limestone into the mining faces.

In addition, according to the risk analysis, we found that 2228 mining face was located in the high-risk area. However, there were no notable leakage points and grouting points (as can be seen from Figure 8). We believed the main reason for the high-risk score of water inrush could be attributed to the high contribution of natural gamma and other parameters in this area (Figure 10). During the operation started at 2228 mining face after initial grouting at all other locations, water inrush occurred 
Table 5: Water inrush accidents occurred due to water from the Ordovician limestone.

\begin{tabular}{lccccc}
\hline $\begin{array}{l}\text { Water } \\
\text { inrush location }\end{array}$ & $\begin{array}{c}\text { Water } \\
\text { inrush time }\end{array}$ & $\begin{array}{c}\text { Peak water value } \\
\left(\mathrm{m}^{3} / \mathrm{h}\right)\end{array}$ & $\begin{array}{c}\text { Stability water } \\
\text { volume }\left(\mathrm{m}^{3} / \mathrm{h}\right)\end{array}$ & $\begin{array}{c}\text { Observation } \\
\text { borehole distance }(\mathrm{m})\end{array}$ & $\begin{array}{c}\text { Water levels } \\
\text { fall }(\mathrm{m})\end{array}$ \\
\hline 2127 mining face & 2011.4 .13 & 210 & 142 & 800 & 28.662 \\
2125 mining face & 2014.5 .19 & 150 & 92 & 720 & 71.98 \\
2222 mining face & 2015.3 .1 & 268 & 200 & 724 & 44.593 \\
\hline
\end{tabular}
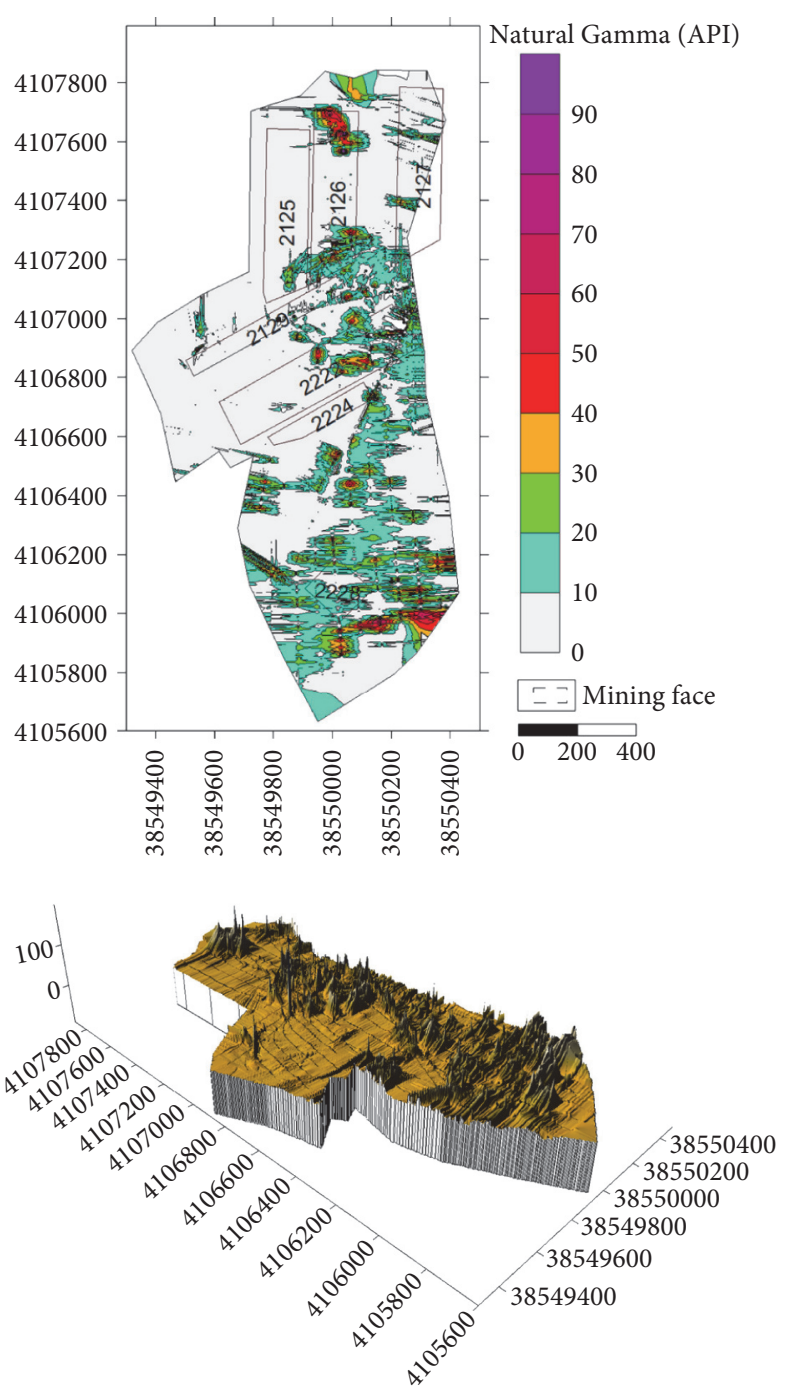

Figure 10: The plane and profile of natural gamma value.

in this mining face, and the maximum amount of water inrush reached $2650 \mathrm{~m}^{3} / \mathrm{h}$. By means of infilling boreholes and supplementing grouting, the floor conditions were gradually improved and the water inrush volume was gradually reduced.

\section{Conclusions}

Application of the new technique that combines horizontal directional drilling and cement grouting capable of detecting and plugging fractures and faults and preventing water inrush during coal mining enabled us to obtain useful data reflecting hydrogeological conditions from different aspects. The grouting quantity was mainly affected by the loss of drilling fluid, gamma value, water temperature, average water absorption, distance between grouting loss points, water pressure on coal seam floor, and aquifuge thickness. Adopting the data fusion method based on grey system theory, these factors thus can be used to quantitatively assess water inrush risk at the coal seam floor.

Through the grey system evaluation of these factors, we calculated the comprehensive scores of water inrush risk and drew the contour map. According to the comprehensive score contour map, the three water inrushes from the Ordovician limestone previously occurred in mining faces 2127,2125 , and 2222 were all located in the areas with risk scores higher than 65 . Through grouting, the identified cracks were effectively blocked, and the water-proof layers beneath the floors of the three mining faces were constructed. These remediation efforts thus reduced the threat of water inrush from the Ordovician limestone into the mining faces.

Comparing with the previous studies that mainly consider aquifuge thickness and water pressure on the coal seam floor, the new technique adopted in this study has advantages which enable collecting a number of aforementioned factors. These factors can then be integrated and analyzed with an evaluation method to quantitatively evaluate the risk of floor water inrush. By comparing the risk assessment with three water inrush events occurred before grouting operations, we found that water inrush events are concentrated in the vicinity of risky areas. The risk assessment also predicted the water inrush event at 2228 face of the mine. These findings convinced the robustness of our approach.

\section{Data Availability}

The data used to support the findings of this study are available from the corresponding authors, upon reasonable request.

\section{Conflicts of Interest}

The authors declare that they have no conflicts of interest.

\section{Acknowledgments}

This work was partially supported by the National Key Research and Development Program of China (no. 2017YFC0804102), Key project of funds for scientific and technological innovation and entrepreneurship of Tiandi Science and Technology Co. Ltd. (no. 2019TDZD003), Natural Science Foundation of Tianjin, China (no. 18JCZDJC39500), Program for Innovative Research Team in Universities of Tianjin (no. TD13-5078), and National Natural Science Foundation of China (nos. 41272245, 
40972165, and 40572150). The authors sincerely thank the seven anonymous reviewers for their detailed and constructive comments to improve the quality of this manuscript.

\section{References}

[1] X. Shi, S. Zhu, and W. Zhang, "Study on the mechanisms and prevention of water inrush events in a deeply buried highpressure coal seam - a case study of the Chensilou coal mine in China," Arabian Journal of Geosciences, vol. 12, no. 19, p. 614, 2019.

[2] Y. Qian, H. Jing, R. Liu et al., "Experimental study on stressdependent nonlinear flow behavior and normalized transmissivity of real rock fracture networks," Geofluids, vol. 2018, Article ID 8217921, 16 pages, 2018.

[3] H. Su, H. Jing, H. Zhao, L. Yu, and Y. Wang, "Strength degradation and anchoring behavior of rock mass in the fault fracture zone," Environmental Earth Sciences, vol. 76, no. 4, pp. 1-11, 2017.

[4] O. Sammarco, "Spontaneous inrushes of water in underground mines," International Journal of Mine Water, vol. 5, no. 3, pp. 29-42, 1986.

[5] O. Sammarco, "Inrush prevention in an underground mine," International Journal of Mine Water, vol. 7, no. 4, pp. 43-52, 1988.

[6] D. Kuscer, "Hydrological regime of the water inrush into the kotredez coal mine (Slovenia, yugoslavia)," Mine Water and the Environment, vol. 10, no. 1, pp. 93-102, 1991.

[7] A. K. Dash, R. M. Bhattacharjee, and P. S. Paul, "Lessons learnt from Indian inundation disasters: an analysis of case studies," International Journal of Disaster Risk Reduction, vol. 20, pp. 93-102, 2016.

[8] P. Bukowski, "Water hazard assessment in active shafts in Upper Silesian coal basin mines," Mine Water and the Environment, vol. 30, no. 4, pp. 302-311, 2011.

[9] Q. Wu, D. Zhao, Y. Wang, J. Shen, W. Mu, and H. Liu, "Method for assessing coal-floor water-inrush risk based on the variable-weight model and unascertained measure theory," Hydrogeology Journal, vol. 25, no. 7, pp. 2089-2103, 2017.

[10] H. Liu and Y. Cao, "Technologies of preventing coal mine water hazards for sustainable development in north China," Geotechnical and Geological Engineering, vol. 29, no. 1, pp. 1-5, 2011.

[11] Q. Wu, H. Xu, and W. Pang, "GIS and ANN coupling model: an innovative approach to evaluate vulnerability of karst water inrush in coalmines of north China," Environmental Geology, vol. 54, no. 5, pp. 937-943, 2008.

[12] G. Dai, X. Xue, K. Xu, L. Dong, and C. Niu, "A GIS-based method of risk assessment on no. 11 coal-floor water inrush from Ordovician limestone in Hancheng mining area, China," Arabian Journal of Geosciences, vol. 11, no. 22, pp. 1-10, 2018.

[13] Y. Zeng, Q. Wu, S. Liu et al., "Vulnerability assessment of water bursting from Ordovician limestone into coal mines of China," Environmental Earth Sciences, vol. 75, no. 22, p. 1431, 2016.

[14] H. Li, H. Bai, J. Wu et al., "A set of methods to predict water inrush from an ordovician karst aquifer: a case study from the Chengzhuang mine, China," Mine Water and the Environment, vol. 38, no. 1, pp. 39-48, 2019.

[15] Y. Wang, W. Yang, M. Li, and X. Liu, "Risk assessment of floor water inrush in coal mines based on secondary fuzzy comprehensive evaluation," International Journal of Rock Mechanics and Mining Sciences, vol. 52, pp. 50-55, 2012.

[16] D. Huang, Z. Liu, W. Wang et al., "The identification of fault zones in deep karst aquifer of North China coal mine using parallel directional well logs," Environmental Earth Sciences, vol. 77, p. 761, 2018.

[17] S. Liu and Y. Lin, An Introduction to Grey Systems: Foundations, Methodology and Applications, IIGSS Academic Publisher, Slippery Rock, PA, USA, 1998.

[18] S. Liu and Y. Lin, Grey Information: Theory and Practical Applications, Springer-Verlag, London, UK, 2006.

[19] W. Li, "Applying grey system theory to evaluate the relationship between industrial characteristics and innovation capabilities within Chinese high-tech industries," Grey Systems: Theory and Application, vol. 6, no. 2, pp. 143-168, 2016.

[20] J. Chen, R. Zhang, and B. Liu, "The empirical study of executive compensation in China port and shipping listed companies based on the grey relational analysis," Grey Systems: Theory and Application, vol. 6, no. 2, pp. 259-269, 2016.

[21] C. Xie, J. Feng, K. Zhang, H. Zhou, and S. Xue, "Water use efficiency and influencing factors in the Mekong River Basin Region based on grey relational analysis," Journal of Grey System, vol. 2, no. 30, pp. 28-41, 2018.

[22] S. Liu, The Grey System Theory and its Application, 8th edition, Sciencepress, Beijing, China, 2017, in Chinese,

[23] Q. Yang, W. Liu, and T. Long, "Correlation between rural finance development and economic growth in xinjiang," Guizhou Agricultural Sciences, vol. 43, no. 5, pp. 243-246, 2005, in Chinese.

[24] C. Yuan, B. Guo, and H. Liu, "Assessment and classification of China's provincial regional innovation system based on grey fixed weight clustering," Grey Systems: Theory and Application, vol. 3, no. 3, pp. 316-337, 2013.

[25] A. Delgado and I. Romero, "Environmental conflict analysis using an integrated grey clustering and entropy-weight method: a case study of a mining project in Peru," Environmental Modelling \& Software, vol. 77, pp. 108-121, 2016.

[26] L. Wang, "Planning optimization of the urban rail transit network based on improved grey fixed weight clustering," Journal of Transport Information and Safety, vol. 29, no. 4, pp. 48-57, 2011, in Chinese.

[27] X. Wang and J. Luo, Brief Course of Grey System Method, Chengdu University of Science and Technology Press, Chengdu, China, 1993, in Chinese.

[28] D. Mao, Z. Liu, W. Wang et al., "An application of hydraulic tomography to a deep coal mine: combining traditional pumping tests with water inrush incidents," Journal of $\mathrm{Hy}$ drology, vol. 567, pp. 1-11, 2018.

[29] J. Guo, "Introduction and development of the grouting technology," Shanxi Science \& Technology of Communications, vol. S1, pp. 86-88, 2003, in Chinese.

[30] P. Li, "Research on slurry diffusion law of horizontal grouting hole in ordovician karst fissure aquifer," Master thesis, China Coal Research Institute, Xi'an, China, 2018, (in Chinese). 